\title{
A challenging diagnosis of occult breast cancer in men: a case report
}

\author{
David Guillermo Gómez Garnica ${ }^{1}$, Catalina Barco-Castillo ${ }^{2}$, Diego Vanegas ${ }^{1}$, Mónica Sofía Benavides $^{3}$, \\ María Helena Astorquiza ${ }^{3}$
}

${ }^{1}$ Department of General Surgery, Hospital Militar Central, Bogotá DC, Colombia and Universidad Militar Nueva Granada School of Medicine, Bogotá DC, Colombia; ${ }^{2}$ Department of Urology, Hospital Militar Central, Bogotá DC, Colombia and Universidad Militar Nueva Granada School of Medicine, Bogotá DC, Colombia; ${ }^{3}$ Department of Pathology, Hospital Militar Central, Bogotá DC, Colombia and Universidad Militar Nueva Granada School of Medicine, Bogotá DC, Colombia

Correspondence to: David Guillermo Gómez Garnica, MD. General Surgeon, TV 3C 49 02, fifth floor, Department of General Surgery, Hospital Militar Central, Bogotá DC, Colombia. Email: davidg.gomezg@outlook.com.

\begin{abstract}
We present a case of a 38-year-old male patient with a left axillary metastatic mass without evidence of the primary lesion. Needle aspiration biopsy was performed showing a human epidermal growth factor receptor 2 (HER2) positive occult breast cancer (OBC). The patient underwent neoadjuvant chemotherapy and radical modified mastectomy followed by radiotherapy and systemic therapy. Genetic studies were negative, and the follow-up showed no relapse. OBC is defined as a mammary gland neoplasm that presents as a metastatic disease without clinical or radiological manifestation of the primary tumor. The incidence of $\mathrm{OBC}$ in men is unknown and is limited to case reports. A systematic review was performed including eleven case reports with twelve patients ranging from 29 to 83 years old. Estrogen and progesterone receptors were positive in seven patients of which two patients were also HER-2 positive; one patient presented only progesterone receptors, two presented only HER-2 positive and two were triplenegative. Operative management, hormonal therapy, chemotherapy, and radiotherapy were performed together or apart depending on the attending and the patient's preferences. No one reported mortality due to malignant disease. OBC is a rare pathology in men and requires a high diagnostic suspicion in patients with an axillary or thoracic metastatic disease without an evident primary neoplasm. The genetic study is necessary to determine mutations and evaluate the risk of relapse and the high risk of primarily associated neoplasm in the patient and family.
\end{abstract}

Keywords: Occult breast cancer (OBC); men; axillary adenopathy; metastatic disease; case report

Received: 03 June 2021; Accepted: 18 March 2022; Published: 30 September 2022.

doi: 10.21037/asj-21-44

View this article at: https://dx.doi.org/10.21037/asj-21-44

\section{Introduction}

Occult breast cancer (OBC) is a mammary gland neoplasm that presents as a metastatic disease without clinical or radiological manifestation of the primary tumor (1). The most frequent finding is axillary or thoracic adenopathy presented as a painful mass, the reason why patients consult (1). The incidence of $\mathrm{OBC}$ in men is unknown and is limited to case reports. OBC is a challenge for the physician due to the need to rule out all the most prevalent cancers in men before the diagnosis. This study aims to present a case of a 38-year-old male patient with human epidermal growth factor receptor 2 (HER2) positive OBC and the corresponding systematic review of cases that described related clinical and histopathological features,

^ ORCID: 0000-0002-5137-944X. 


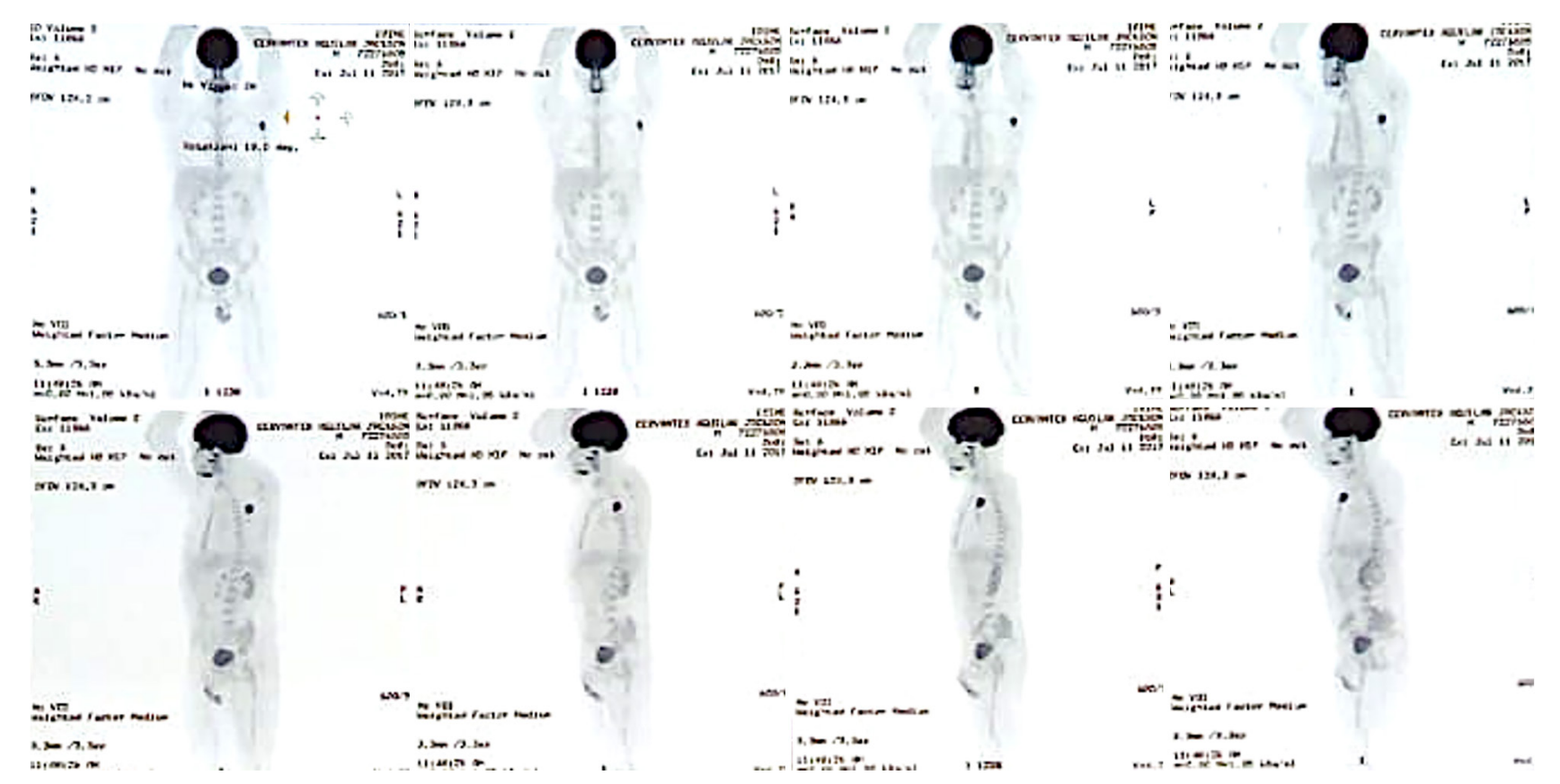

Figure 1 PET-CT scan with hypermetabolic activity in the left axillary region. PET-CT, positron emission tomography-computerized tomography.

management, clinical course, and follow-up. We present the following case in accordance with the CARE reporting checklist (available at https://asj.amegroups.com/article/ view/10.21037/asj-21-44/rc).

\section{Case presentation}

A 38-year-old male patient with no relevant medical or family history consulted due to the appearance of a painless left axillary mass without other symptoms since a month ago. On physical examination, findings of a mobile, soft, and non-attached to deep planes $5 \mathrm{~cm} \times 7 \mathrm{~cm}$ lymph node conglomerate in the left axillary region without changes in the skin. A mammary and axillary ultrasound was performed reporting fatty mammary parenchyma without evidence of lesions, but an axillary lymph node conglomerate that measured $78 \mathrm{~mm} \times 34 \mathrm{~mm}$ and presented hyperechogenic images inside suggesting calcification. Chest CT-scan was negative for adenomegalies or mediastinal masses, however, reported the left lymph node conglomerate that measured $57 \mathrm{~mm} \times 48 \mathrm{~mm} \times 98 \mathrm{~mm}$. The breast magnetic resonance imaging (MRI) was negative to focal lesions or alterations on muscle tissues. Mammogram was not performed due to small mammary tissue that difficult the development and the quality of the image, and other studies showed no abnormalities.

Positron emission tomography-computerized tomography (PET-CT) scan was performed with evidence of a high-grade hypermetabolic conglomerate in the left axillary region with an SUV of 10.8 without pathological findings in the breast or mediastinum (Figure 1). An incisional ultrasound-guided core needle biopsy of lymphadenopathies was performed and confirmed involvement of a non-special moderately differentiated ductal carcinoma of the mammary gland, with a positive immunohistochemical profile for CK-7, GATA3, GCDFP-15, and mammaglobin. Estrogen (ER) and progesterone receptors (PR), and CK-20 were negative while HER-2 (3+) was positive, and a Ki-67 cell proliferation index was $30 \%$ (Figure 2). It was considered metastatic infiltration due to moderately differentiated ductal carcinoma of the mammary gland.

Neoadjuvant Adriamycin and Cyclophosphamide chemotherapy was administered in four cycles with sequential Paclitaxel and Trastuzumab, and lymph node axillary dissection three weeks after completion of chemotherapy. During surgery, a left axillary lymph node conglomerate was observed with adenopathies between 5 and $10 \mathrm{~mm}$. In the specimen, sixteen lymph nodes were resected and one presented involvement of poorly differentiated carcinoma foci with areas of necrosis. Breast 

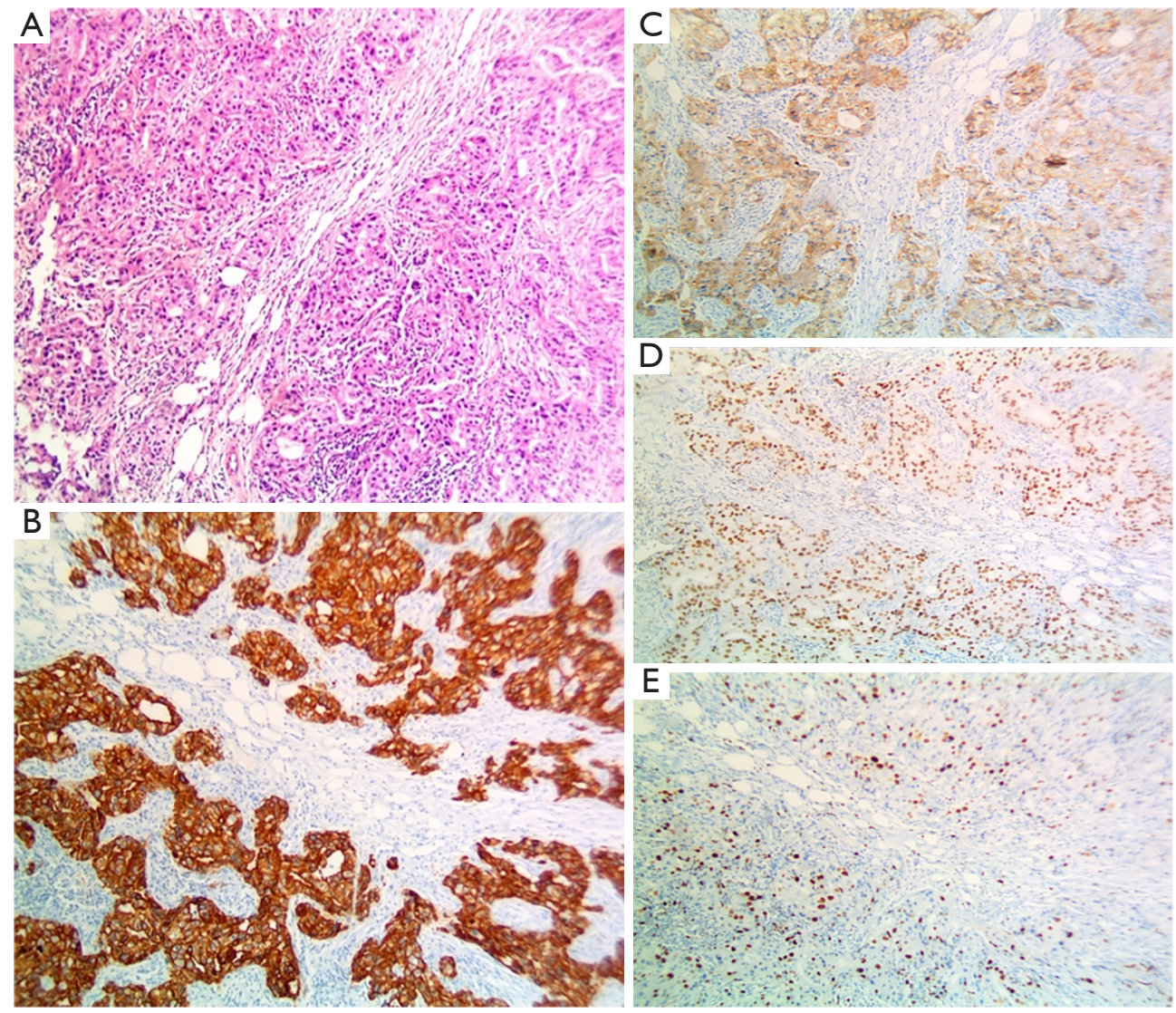

Figure 2 Incisional biopsy histology and immunohistochemical profile at $10 \times$ photomicrograph. (A) HE staining with moderately differentiated non-special type ductal adenocarcinoma. (B) CK-7 with strong cytoplasmic and membrane reactivity (IHC staining); (C) HER-2 with complete membrane reactivity in $90 \%$ of tumor cells (IHC staining); (D) GATA-3 favoring carcinoma of the breast as the primary tumor (IHC staining); (E) Ki-67 with nuclear reactivity of 30\% in tumor cells (IHC staining). HE, haemotoxylin and eosin; IHC, immunohistochemistry; HER-2, human epithelial factor receptor 2.

cancer was classified as ypT0pN2M0 stage IIIB. The patient case was taken to the breast surgery, oncology and radiotherapy board and a partial response of the tumor was considered. Reason why, radiotherapy was performed in the axillary region. As a primary tissue should have been controlled too, the patient was taken to a left modified radical mastectomy. The histopathological study of the mastectomy specimen was negative for the residual tumor. The patient received adjuvant management with Trastuzumab for nine months until completing eighteen doses.

Genetic studies with the 30-gene GENCELL PHARMA $^{\mathrm{TM}}$ panel were performed, with all gene mutations negative, including BRCA1 and BRCA2. On a 3-year followup, the patient had no clinical or radiological signs of recurrence.
All procedures performed in this study were in accordance with the ethical standards of the institutional and/or national research committee(s) and with the Helsinki Declaration (as revised in 2013). Written informed consent was obtained from the patient for publication of this case report and accompanying images. A copy of the written consent is available for review by the editorial office of this journal.

\section{Systematic review}

The present analysis was conducted according to the 2009 preferred reporting items for systematic review. Search strategies included two separate reviewers and the following terms: ("male AND occult breast cancer") OR ("male AND occult breast cancer AND case report ") OR ("male 


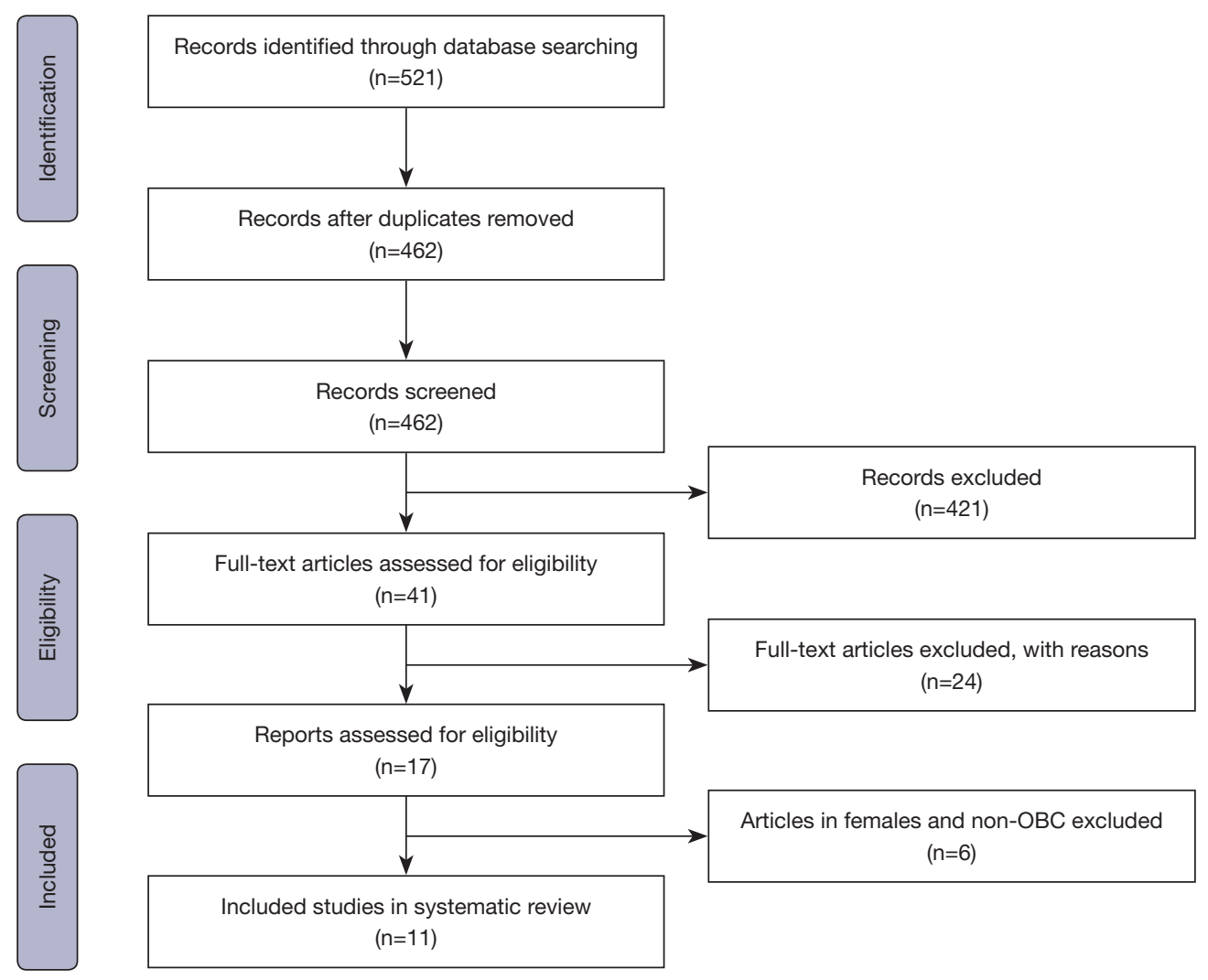

Figure 3 PRISMA diagram for literature search. OBC, occult breast cancer.

AND occult breast cancer AND case report AND HER2") in OVID, MEDNAR, Embase, Scopus, Web of Science, PubMed, and CENTRAL databases. The search was not limited to location or date of publication. A hand search of the reference list of the articles selected was performed. All cases in English and Spanish that reported male patients with $\mathrm{OBC}$ were included. Gray literature was excluded.

A total of 521 articles were found, duplicates were removed for an evaluation of 462 studies. All studies different for case reports were excluded and 41 articles remained. Out of these, 17 studies were assessed eligibility by two reviewers, and articles that did not correspond to $\mathrm{OBC}$ in men were excluded. Finally, 11 studies were identified and included in the systematic review (Figure 3).

The information extracted included: first author's last name, country, publication year, number of patients, baseline characteristics of the patients, tumor characteristics and staging, histopathological and immunohistochemical evaluation, imaging, management, and follow-up.

The overall quality of the cases was good to moderate. Most cases reported an adequate description of the patient's past medical history, laboratory image investigation, and treatments, however, a few cases did not report convincing evidence of follow-up.

Ages ranged between 29 and 83 years old. ER and PR were positive in seven patients of which two patients were also HER-2 positive; one patient presented only progesterone receptors, two presented only HER-2 positive and two were triple-negative. Most of the patients had no family history or risk factors to develop breast cancer, however, 9 out of 12 patients, were diagnosed in stage III and IV. No patients underwent a genetic counseling.

Operative management, hormonal therapy, chemotherapy, and radiotherapy were performed together or apart depending on the attending and the patient preferences: 2 patients were only treated with surgery, 2 patients were not operated on and managed only with chemotherapy, 2 patients underwent surgery and radiotherapy, 2 more patients were managed with surgery and radio and chemotherapy, one patient underwent surgery and received hormone and chemotherapy, and 3 patients underwent all four therapies together. All data is reported in Table 1. 
Table 1 Systematic review of case reports of male patients with occult breast cancer

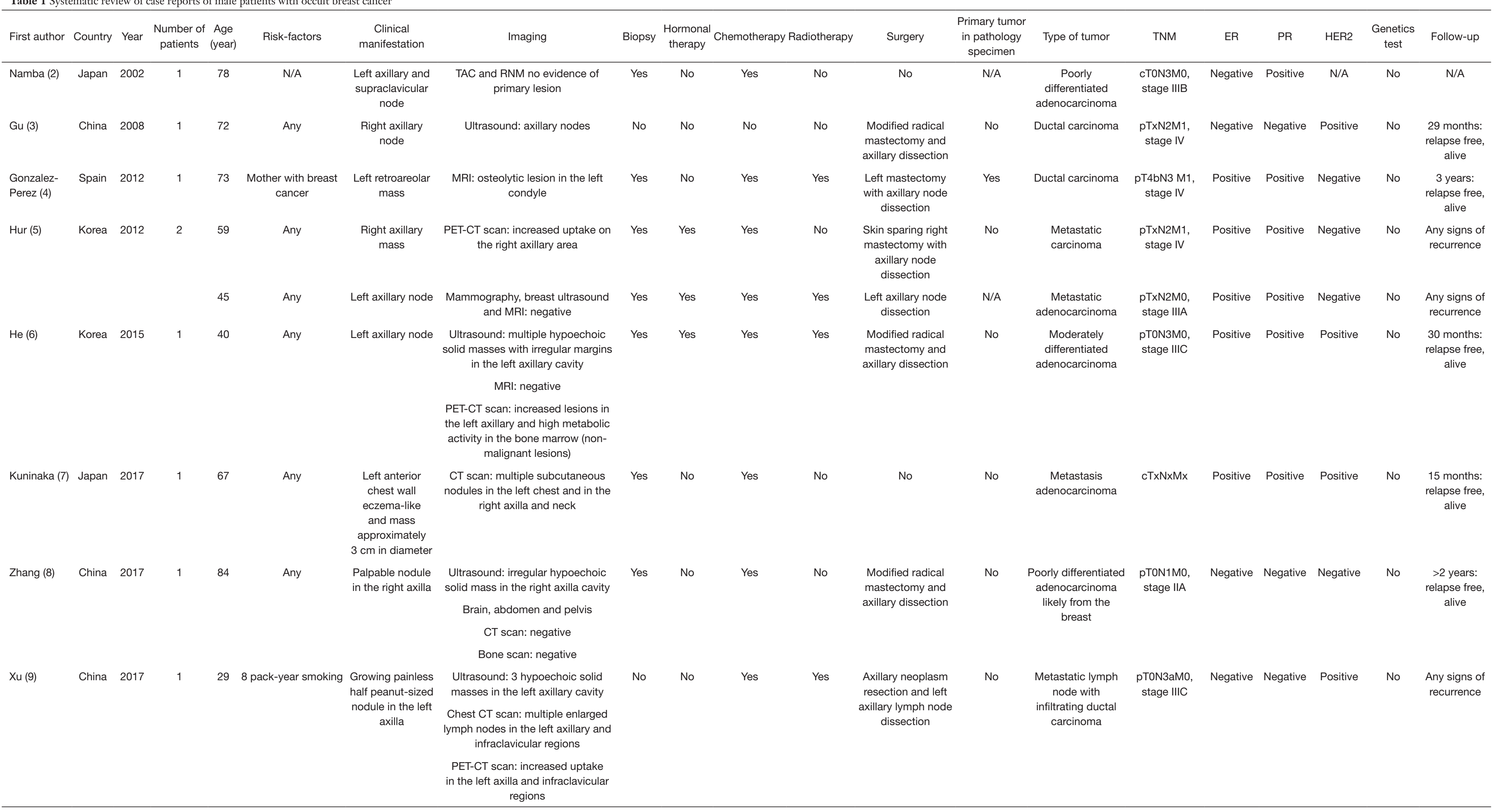

Table 1 (continued) 
Table 1 (contimued)

\begin{tabular}{|c|c|c|c|c|c|c|c|c|c|c|c|c|c|c|c|c|c|c|c|c|}
\hline First author & Country & Year & $\begin{array}{c}\text { Number of } \\
\text { patients }\end{array}$ & $\begin{array}{l}f \begin{array}{l}\text { Age } \\
\text { (year) }\end{array}\end{array}$ & Risk-factors & $\begin{array}{l}\text { Clinical } \\
\text { manifestation }\end{array}$ & Imaging & Biopsy & $\begin{array}{l}\text { Hormonal } \\
\text { therapy }\end{array}$ & Chemotherapy & Radiotherapy & Surgery & $\begin{array}{l}\text { Primary tumor } \\
\text { in pathology } \\
\text { specimen }\end{array}$ & Type of tumor & TNM & ER & PR & HER2 & $\begin{array}{l}\text { Genetics } \\
\text { test }\end{array}$ & Follow-up \\
\hline \multirow[t]{2}{*}{ Wang (10) } & \multirow[t]{2}{*}{ China } & \multirow[t]{2}{*}{2018} & \multirow[t]{2}{*}{1} & \multirow[t]{2}{*}{49} & \multirow[t]{2}{*}{$\begin{array}{l}\text { Smoking and drinking } \\
\text { for }>30 \text { years }\end{array}$} & \multirow[t]{2}{*}{$\begin{array}{l}\text { Painless quail } \\
\text { egg-sized mass } \\
\text { in the left axilla }\end{array}$} & $\begin{array}{l}\text { Breast ultrasound: multiple } \\
\text { hypoechoic solid masses in the left } \\
\text { axilla }\end{array}$ & \multirow[t]{2}{*}{ Yes } & \multirow[t]{2}{*}{ Yes } & \multirow[t]{2}{*}{ Yes } & \multirow[t]{2}{*}{ Yes } & \multirow[t]{2}{*}{$\begin{array}{l}\text { Left axillary lymph } \\
\text { node dissection }\end{array}$} & \multirow[t]{2}{*}{ No } & \multirow[t]{2}{*}{$\begin{array}{c}\text { Metastatic } \\
\text { adenocarcinoma } \\
\text { from the breast }\end{array}$} & \multirow[t]{2}{*}{$\begin{array}{l}\text { pTON3aMO, } \\
\text { stage IIIC }\end{array}$} & \multirow[t]{2}{*}{ Positive } & \multirow[t]{2}{*}{ Positive } & \multirow[t]{2}{*}{ Negative } & \multirow[t]{2}{*}{ No } & \multirow[t]{2}{*}{ N/A } \\
\hline & & & & & & & $\begin{array}{l}\text { PET-CT scan: increased uptake } \\
\text { in the left axilla and infraclavicular } \\
\text { regions }\end{array}$ & & & & & & & & & & & & & \\
\hline \multirow[t]{3}{*}{ Alsayed (11) } & \multirow[t]{3}{*}{$\begin{array}{l}\text { Saudi } \\
\text { Arabia }\end{array}$} & \multirow[t]{3}{*}{2019} & \multirow[t]{3}{*}{1} & \multirow[t]{3}{*}{82} & \multirow[t]{3}{*}{ Any } & \multirow{3}{*}{$\begin{array}{l}\text { Redness of the } \\
\text { left lateral chest } \\
\text { wall associated } \\
\text { with painless } \\
\text { mass in the left } \\
\text { axilla }\end{array}$} & $\begin{array}{l}\text { Ultrasound: solid and cystic lesion } \\
\text { in subcutaneous tissue of the left } \\
\text { axilla }\end{array}$ & \multirow[t]{3}{*}{ Yes } & \multirow[t]{3}{*}{ No } & \multirow[t]{3}{*}{ No } & \multirow[t]{3}{*}{ No } & \multirow[t]{3}{*}{$\begin{array}{l}\text { Left modified radical } \\
\text { mastectomy and } \\
\text { axillary dissection }\end{array}$} & \multirow[t]{3}{*}{ Yes } & \multirow[t]{3}{*}{$\begin{array}{l}\text { Invasive ductal } \\
\text { carcinoma }\end{array}$} & \multirow[t]{3}{*}{$\begin{array}{l}\text { pT3N2Mx, stage } \\
\text { IIIA }\end{array}$} & Negative & Negative & Negative & No & N/A \\
\hline & & & & & & & $\begin{array}{l}\text { Thorax, abdomen and pelvis CT } \\
\text { scan: negative }\end{array}$ & & & & & & & & & & & & & \\
\hline & & & & & & & Bone scan: negative & & & & & & & & & & & & & \\
\hline Sood (12) & India & 2020 & 1 & 83 & $\begin{array}{l}\text { Chemotherapy } \\
\text { and right axillary } \\
\text { mass resection } \\
\text { with ipsilateral } \\
\text { conservative } \\
\text { mastectomy } 14 \text { years } \\
\text { ago: amelanotic } \\
\text { melanoma }\end{array}$ & $\begin{array}{l}\text { Right axillary } \\
\text { mass }\end{array}$ & Bilateral mammogram: normal & Yes & No & Yes & No & $\begin{array}{l}\text { En bloc excision of } \\
\text { the mass with right } \\
\text { axillary dissection }\end{array}$ & Yes & $\begin{array}{l}\text { Solid papillary } \\
\text { carcinoma in the } \\
\text { specimen pathology }\end{array}$ & $\begin{array}{l}\text { pT1bNOMO, } \\
\text { stage IA }\end{array}$ & Positive & Positive & Negative & No & $\begin{array}{l}\text { Three negative } \\
\text { PET-CT scan } \\
\text { till date }\end{array}$ \\
\hline
\end{tabular}

TNM, tumor, node, metastasis; ER, estrogen receptor; PR, progesterone receptor; HER2, human epidermal growth factor receptor 2; N/A, not available; TAC, total area coverage; MRI, magnetic resonance imaging; PET-CT, positron emission tomography-computerized tomography. 


\section{Discussion}

Breast cancer in men is a rare disease. OBC is defined as a mammary gland neoplasm without any symptoms or signs that could be identified on the interrogatory or the physical examination, nor diagnostic images (1). The first expression of OBC is usually metastatic adenopathy in the infra or supraclavicular fossa and is more frequently localized in the axilla (5), as in our case. The most common causes of malignant axillary lymph nodes include metastatic breast cancer, lymphoma, lung cancer, melanoma, and squamous cell carcinoma (3). This challenges the physician due to the need to rule out all the most prevalent cancers in men before the diagnosis.

In women, OBC has an incidence ranging from $0.3 \%$ to $0.8 \%$, and in men, it is extremely rare, limited to case reports (13). Risk factors include a family history of breast cancer, obesity, cryptorchidism, orchitis, infertility, Klinefelter syndrome, previous chest radiotherapy, and changes in the estrogen index (14). In the articles reviewed, most patients were Asians with no relevant medical or family history, which lead to the study of habits, exposition to estrogen changing chemicals, and genetics associated with breast cancer in males.

It is reported that mutations in the $B R C A 1$ or $B R C A 2$ genes were found in up to $40 \%$ of cases of male breast cancer, being the $B R C A 2$ the most common mutated gene (11). All physicians with a case of breast cancer in men, occult or not, should perform genetic counseling to the patients and their families. In this systematic review, any patient underwent a genetic study. In our case, a genetic study with a panel of 30 genes was performed, and specific mutations for $B R C A 1$ and $B R C A 2$ genes were negative so family members were not included in the genetic counseling. However, in cases with positive gene profile, would be important to include the patient and its family in screening programs for other cancers associated with the mutations found, and prevent advanced disease and mortality associated.

Diagnostic images have an important role, so they must be performed to find the primary tumor. The breast MRI let the physician discover hidden lesions in $59 \%$ of cases that have not been observed with other imaging modalities $(12,15)$. In this review, any patient presented hidden lesions when studied with ultrasound, CT-scan, MRI, or PETCT scan $(2,8,10)$. Also, when patients underwent surgery, a primary tumor in the pathology of the specimen was only found in three cases $(4,11,12)$, which represents the challenge of the diagnosis. In our patient, axillary ultrasound showed pathological lymph nodes and was used for guiding biopsy. Meanwhile, chest CT-scan and breast MRI did not show a primary hidden lesion, and the PETCT scan showed a high-grade hypermetabolic lymph node conglomerate without pathological findings in the mediastinum.

Usually, in male breast cancer, ER and PR are expressed in more than $90 \%$ and $80 \%$ of cases, respectively. So, the identification of receptors is key for diagnosis, and evaluation to determine the necessity of hormonal therapy (5). In this review, ER and PR were positive in seven patients of which two patients were also HER-2 positive; one patient presented only progesterone receptors, two presented only HER-2 positive and two were triple-negative $(3,7,9)$. Positive HER-2 breast cancer is seen in approximately 25$30 \%$ of cases and confers worse biological behavior $(7,16)$. Our case was ER and PR negative, and HER-2 positive, which lead to discarding hormonal therapy.

The diagnosis of metastatic disease requires a panel of cytokeratins to consider the primary site of the malignant tumor (9). The CK-7 is usually expressed in up to $90 \%$ of cases, while CK-20 is usually negative (9). The GCDFP-15 has a positive predictive value and a specificity of $90 \%$ for breast carcinoma, and other markers such as GATA3 and mammaglobin, have sensitivity but low specificity to favor mammary gland origin (17). The final diagnosis of our case was made after a histopathological and immunohistochemical evaluation of the specimen resected during the axillary lymph node dissection (ALND), and reactivity for CK-7, GCDFP-15, and GATA-3 with negative CK-20.

HER-2 amplification in breast cancer is an early event of tumorigenesis and is seen in nearly $50 \%$ of all in situ ductal carcinomas without any evidence of invasive disease (18-20). However, it is maintained during progression to invasive disease, and nodal and distant metastasis (19). The presence of HER-2 in our patient and the absence of ER and PR could be the explanation of the $\mathrm{OBC}$ as a ductal carcinoma without evidence of invasive primary tumor but nodal metastasis. However, it was only seen in two more cases of our review, and HER-2 was positive in a total of 4 patients, so further studies of the association are needed.

Treatment of breast cancer and OBC in men is based on the treatments given to women due to the rare incidence of the disease. Regarding surgical treatment, the conservative approach is not recommended in men and a modified radical mastectomy should be performed in all cases due to the 
advanced stage in which male patients are usually diagnosed $(5,21)$. Hereby, ten cases underwent surgery with ALND of which six patients were taken to mastectomy too. More studies are needed to attribute surgical mastectomy or breast radiotherapy of $\mathrm{OBC}$ to disease-free and overall survival.

The status of the axillary lymph nodes is one of the prognostic factors in patients with breast cancer, thus, postoperative radiation is recommended if mastectomy is not performed (9). In the literature, most of the patients were diagnosed in an advanced stage (III and IV) and needed directed therapies. For instance, our patient needed neoadjuvant chemotherapy with Adriamycin and Cyclophosphamide, and after ALND, Paclitaxel, and Trastuzumab due to partial response to neoadjuvancy, and the presence of HER-2 with negative ER and PR. In the three years follow-up, our patient continued without evidence of tumor relapse despite the aggressive HER-2 positive OBC. This could be related to the mastectomy surgical approach and the directed therapy with Trastuzumab.

Limitations of our study include the small number of cases we found, and that we should not meta-analyze a case report systematic review. However, in this study we highlight and recommend an exhaustive performance of different images for the first suspicion of the primary tumor to make an early diagnosis. Also, the confirmation with biopsy to decide the complete multidisciplinary management, considering the histological aggressiveness of HER2 and the consequent morbidity and mortality of the patient. The genetic counseling is innovative in our case and it should be mandatory even in low-genetic-risk patients to study completely the risk of recurrence or development of another primary tumor, and the familiar risk of breast or other related cancers in both men and women, improving the follow-up.

\section{Conclusions}

$\mathrm{OBC}$ is a rare pathology in men and requires a high diagnostic suspicion in patients with an axillary or thoracic metastatic disease without an evident primary neoplasm. All management should be based on the patient's findings, location of the metastasis, and immunohistochemical evaluation. The genetic study is necessary to determine mutations and evaluate the risk of relapse and the high risk of primarily associated neoplasm in the patient and family.

\section{Acknowledgments}

Funding: None.

\section{Footnote}

Reporting Checklist: The authors have completed the CARE reporting checklist. Available at https://asj.amegroups.com/ article/view/10.21037/asj-21-44/rc

Peer Review File: Available at https://asj.amegroups.com/ article/view/10.21037/asj-21-44/prf

Conflicts of Interest: All authors have completed the ICMJE uniform disclosure form (available at https://asj.amegroups. com/article/view/10.21037/asj-21-44/coif). The authors have no conflicts of interest to declare.

Ethical Statement: The authors are accountable for all aspects of the work in ensuring that questions related to the accuracy or integrity of any part of the work are appropriately investigated and resolved. All procedures performed in this study were in accordance with the ethical standards of the institutional and/or national research committee(s) and with the Helsinki Declaration (as revised in 2013). Written informed consent was obtained from the patient for publication of this case report and accompanying images. A copy of the written consent is available for review by the editorial office of this journal.

Open Access Statement: This is an Open Access article distributed in accordance with the Creative Commons Attribution-NonCommercial-NoDerivs 4.0 International License (CC BY-NC-ND 4.0), which permits the noncommercial replication and distribution of the article with the strict proviso that no changes or edits are made and the original work is properly cited (including links to both the formal publication through the relevant DOI and the license). See: https://creativecommons.org/licenses/by-nc-nd/4.0/.

\section{References}

1. Luna MA, Sánchez Méndez S, Mariscal A, et al. Cáncer oculto de la mama. Caso clínico y revisión de la literatura. Clínica E Investig En Ginecol Obstet 2012;39:21-8.

2. Namba N, Hiraki A, Tabata M, et al. Axillary metastasis as the first manifestation of occult breast cancer in a man: a case report. Anticancer Res 2002;22:3611-3.

3. Gu GL, Wang SL, Wei XM, et al. Axillary metastasis as the first manifestation of male breast cancer: a case report. Cases J 2008;1:285.

4. Gonzalez-Perez LM, Infante-Cossio P, Crespo-Torres 
$\mathrm{S}$, et al. Mandibular metastases as first clinical sign of an occult male breast cancer. Int J Oral Maxillofac Surg 2012;41:1211-4.

5. Hur SM, Cho DH, Lee SK, et al. Occult breast cancers manifesting as axillary lymph node metastasis in men: a two-case report. J Breast Cancer 2012;15:359-63.

6. He M, Liu H, Jiang Y. A Case Report of Male Occult Breast Cancer First Manifesting as Axillary Lymph Node Metastasis With Part of Metastatic Mucinous Carcinoma. Medicine (Baltimore) 2015;94:e1038.

7. Kuninaka K, Takahashi R, Nakagawa Y, et al. A case of HER2-positive male occult breast carcinoma with skin and lymph node metastases that exhibited complete response to trastuzumab monotherapy. Clin Case Rep 2017;5:591-3.

8. Zhang L, Zhang C, Yang Z, et al. Male occult triplenegative breast cancer with dermatomyositis: a case report and review of the literature. Onco Targets Ther 2017;10:5459-62.

9. Xu R, Li J, Zhang Y, et al. Male occult breast cancer with axillary lymph node metastasis as the first manifestation: A case report and literature review. Medicine (Baltimore) 2017;96:e9312.

10. Wang X, Fan L, Yan W, et al. Axillary lymph node metastasis as the first manifestation of male occult breast cancer: A Case Report. Medicine (Baltimore) 2018;97:e13706.

11. Alsayed B, Abdulla HA, Alaskar H, et al. Male occult triple-negative breast cancer. BMJ Case Rep 2019;12:229482.

12. Sood N, Gupta R, Gupta S. Invasive solid papillary carcinoma: Report of the first case presenting as an occult breast carcinoma in a male. Indian J Pathol Microbiol

doi: 10.21037/asj-21-44

Cite this article as: Gómez Garnica DG, Barco-Castillo C, Vanegas D, Benavides MS, Astorquiza MH. A challenging diagnosis of occult breast cancer in men: a case report. AME Surg J 2022;2:30.

\section{0;63:S141-2.}

13. Arnal Burró A, Moreno Reviriego A, González Blanco I, et al. Manifestación clínica atípica de un cáncer oculto de mama. Rev Senol Patol Mamar 2013;26:33-7.

14. Fentiman IS, Fourquet A, Hortobagyi GN. Male breast cancer. Lancet 2006;367:595-604.

15. Pentheroudakis G, Lazaridis G, Pavlidis N. Axillary nodal metastases from carcinoma of unknown primary (CUPAx): a systematic review of published evidence. Breast Cancer Res Treat 2010;119:1-11.

16. Slamon DJ, Godolphin W, Jones LA, et al. Studies of the HER-2/neu proto-oncogene in human breast and ovarian cancer. Science 1989;244:707-12.

17. Kaufmann O, Deidesheimer T, Muehlenberg M, et al. Immunohistochemical differentiation of metastatic breast carcinomas from metastatic adenocarcinomas of other common primary sites. Histopathology 1996;29:233-40.

18. Liu E, Thor A, He M, et al. The HER2 (c-erbB-2) oncogene is frequently amplified in in situ carcinomas of the breast. Oncogene 1992;7:1027-32.

19. Park K, Han S, Kim HJ, et al. HER2 status in pure ductal carcinoma in situ and in the intraductal and invasive components of invasive ductal carcinoma determined by fluorescence in situ hybridization and immunohistochemistry. Histopathology 2006;48:702-7.

20. Moasser MM. The oncogene HER2: its signaling and transforming functions and its role in human cancer pathogenesis. Oncogene 2007;26:6469-87.

21. Angel J, Ibarra J, Diaz S, et al. Comportamiento clínico de cáncer de mama en hombres en una población latinoamericana. Rev Colomb Cancerol 2015;19:150-5. 